\title{
CONSILIUM
}

Berkala Kajian Konseling Dan Ilmu Keagamaan

Avalaible at http://jurnal.uinsu.ac.id/index.php/consilium

ISSN : 2338-0608 (Print) | ISSN : 2654-878X (Online)

\section{Analisis Prokrastinasi Akademik Siswa di Sekolah}

\author{
Erfan Ramadhani', Hikmatus Sadiyah ${ }^{1}$, Ramtia Darma Putri', Rizky Andana \\ Pohan $^{2}$ \\ 1Universitas PGRI Palembang, Indonesia. \\ 2Institut Agama Islam Negeri Langsa, Indonesia. \\ Korespondensi: erfankonselor@gmail.com
}

\begin{abstract}
Procrastination is a behavior that is not good or negative behavior including; neglect in completing assignments, and lack of punctuality when entering school hours. Based on the results of research in the field, it appears that there are students who take academic procrastination, procrastination conducted in the form of procrastinating in completing assignments that result in students being hampered in the learning process at school. This research uses quantitative descriptive methods. The subjects of this study were students of the State High School 1 Muara Sugihan Banyuasin Regency class XII. Based on the results of this study it can be seen that the academic procrastination of Muara Sugihan Middle School 1 Middle School students in Banyuasin Regency is in the High category with a score of 90.92. Thus the expectation of handling the problem is expected so that students can solve the problem. One way to treat the problem is counseling services.
\end{abstract}

Keywords: academic procrastination, students at school.

\begin{abstract}
Abstrak: Prokrastinasi adalah suatu prilaku yang tidak baik atau prilaku yang negatif di antaranya; lalai dalam menyelesaikan tugas, dan kurangnya ketepatan waktu pada saat masuk jam sekolah. Berdasarkan hasil penelitian di lapangan, terlihat bahwa terdapat siswa yang melakukan tindakan prokrastinasi akademik, prokrastinasi yang dilakukan dalam bentuk menunda-nunda dalam menyelesaikan tugas yang mengakibatkan siswa terhambat dalam proses belajar di sekolah. Penelitian ini menggunakan metode deskriptif kuantitatif. Subyek penelitian ini adalah siswa Sekolah Menangah Atas Negeri 1 Muara Sugihan Kabupaten Banyuasin kelas XII. Berdasarkan hasil penelitian ini terlihat bahwa prokrastinasi akademik siswa Sekolah Menangah Atas Negeri 1 Muara Sugihan Kabupaten Banyuasin berada pada kategori Tinggi dengan skor 90,92. Dengan demikian diharapkan adanya penaganan terhadap masalah tersebut sehingga siswa dapat menyelesaikan masalahnya. Salah satu cara penaganan masalah tersebut adalah layanan konseling.
\end{abstract}

Kata kunci: prokrastinasi akademik, siswa di sekolah 


\section{PENDAHULUAN}

S

ekolah sebagai suatu lembaga pendidikan memiliki tanggung jawab yang besar dalam proses pencapaian tujuan pendidikan. Pencapaian tujuan pendidikan dapat diselenggarakan melalui pendidikan formal, pendidikan formal dilakukan agar mampu memberikan pengetahuan dan pemahaman yang berkualitas bagi peserta didik. Ketercapaian pendidikan formal tersebut diperlukan adanya tenaga pendidik yang profesional di bidang keahliannya, salah satunya tenaga kependidikan adalah guru bimbingan dan konseling/kons elor. Guru bimbingan dan konseling sangat berperan untuk membantu pencapaian tujuan pendidikan pada siswa. Guru bimbingan dan konseling sangatlah berperan penting dalam pembentukan pribadi seorang siswa, termasuk mengenali seluruh aspek yang berkaitan dengan kebutuhan siswa. Salah satu aspek dalam pembelajaran adalah pemahaman siswa dalam belajar, pembelajaran adalah proses interaksi antara siswa dengan guru untuk membantu peserta didik agar dapat belajar dengan baik. Pembelajaran yang dilakukan oleh guru merupakan cara yang harus dilakukan dalam proses belajar. Pembelajaran yang dilakukan oleh guru merupakan suatu penguasaan konten tertentu sehingga siswa dapat menguasai kompetensi tertentu sesuai proses pembelajaran yang dicapai. Tujuan pembelajaran yaitu perilaku dari hasil belajar yang diharapkan terjadi, atau dikuasai oleh siswa setelah mengikuti kegiatan pembelajaran. Proses pembelajaran akan berlangsung dengan baik apabila guru bimbingan dan konseling memberikan pembelajaran segenap potensinya dan siswa melaksanakan pembelajaran sesuai dengan fakta yang semestinya. Tidak sedikit proses pembelajaran yang dilakukan terkendala dengan prilaku siswa yang tidak disiplin dalam proses pembelajaran.

Salah satu perilaku yang dilakukan oleh siswa adalah penundaan dalam menyelesaikan tugas (prokrastinasi akademik siswa) terlihat pada siswa-siswi di Sekolah Menegah Atas Negeri 1 Muara Sugihan Kabupaten Banyuasin, diantaranya terdapat siswa yang lalai dalam proses pembelajaran dan lalai dalam menyelesaikan pekerjaan rumah (PR). Berdasarkan informasi yang didapatkan dalam catatan buku dari guru mata pelajaran, dan guru bimbingan dan konseling terlihat 5-10 siswa yang mengerjakan tugas pada saat berada di sekolah. Selanjutnya, ditemukannya siswa yang belum mengerjakan tugas sekolah dikarenakan datang terlambat pada saat jam pelajaran berlangsung, tidur pada saat jam pelajaran, dan sering tidak masuk atau tidak hadir sekolah. Berdasarkan hal tersebut dapat dikatakan bahwa siswa melakukan prokrastinasi akademik bukan hanya pada penyelesaian tugas saja tetapi melakukan penundaan dan lalai dalam melaksanakan tugas sekolah yang dijalaninya.

Belajar merupakan tugas utama seorang siswa, namun tidak semua siswa memiliki pengelolaan belajar yang baik, hal inilah yang dialami Siswa di Sekolah Menegah Atas Negeri 1 Muara Sugihan Kabupaten Banyuasin. Pengelolaan waktu belajar yang kurang baik menyebabkan siswa sering melakukan penundaan dalam 
mengerjakan tugas-tugas akademik. Perilaku menunda tugas-tugas akademik disebut dengan prokrastinasi akademik seperti penundaan dalam menyelesaikan tugas, keterlambatan dalam mengerjakan tugas dengan batas waktu yang ditentukan, menunda-nunda masuk kelas pada saat jam masuk sudah dimulai.

Berdasarkan hasil penelitian (Abdullah, dkk 2016) menunjukkan bahwa telah melakukan penelitian dengan beberapa siklus, siklus pertama presentase perilaku prokrastinasi akademik siswa berkurang sebesar 19,62\%. Sedangkan pada siklus kedua presentase prokrastinasi akademik siswa berkurang sebesar 13,59\%. Hal tersebut di akibatkan oleh pemberian layanan konseling kelompok dengan teknik self management. Jadi, berdasarkan hasil penelitian Abdullah dkk, dapat disimpulkan bahwa prokrastinasi akademik tidak terjadi pada mahasiswa tetapi terjadi juga pada siswa di SMA, dari penelitian tersebut menjadi gambaran bagi peneliti bahwa setelah memberikan gambaran prokrastinasi akademik maka perlunya di berikan layanan secara khusus salah satunya adalah kelompok dengan teknik self management.

Berdasarkan hal tersebut, dapat dipahami bahwa hal itu merupakan tindakan prokrastinasi. Selanjutnya, kelalaian atau penundaan siswa dalam penyelesaian tugas terus terjadi maka akan berdampak negatif pada siswa tersebut. Penundaan dalam melaksanakan tugas tersebut dinamakan dengan prokrastinasi akademik. Prokrastinasi akademik adalah suatu prilaku yang tidak baik dalam memanfaatkan waktu dan adanya kecenderungan untuk tidak segera memulai suatu tindakan atau menunda tugas yang ingin dikerjakan sampai waktu berikutnya, sehingga prilaku penundaan tersebut dapat menghambat pembelajaran individu itu sendiri. Permasalahan yang muncul belum dapat di atasi dengan maksimal, terlihat masih banyak siswa melakukan pelanggaran atau penundaan dalam menyelesaikan tugas. Berdasarkan uraian di atas, dapat disimpulkan bahwa prokrastinasi akademik siswa adalah suatu penundaan tugas seperti pekerjaan rumah (PR), menundanunda waktu masuk sekolah dan penundaan dalam mengumpulkan tugas-tugas dalam jangka waktu yang di tetapkan. Hal ini membuktikan bahwa pembelajaran masih perlu diperbaiki dan di eksplorasi agar pembelajaran dapat berjalan dengan baik dan tidak adanya penundaan berbagai tugas atau yang disebut dengan prokrastinasi akademik siswa.

\section{METODE PENELITIAN}

Desain penelitian yang digunakan pada penelitian ini adalah penelitian Deskriptif Kuantitatif. Menurut Irawan (1996:60) penelitian deskriptif adalah penelitian yang bertujuan mendeskriptifkan atau menjelaskan suatu hal sebagaimana adanya secara aktual. Jenis penelitian yang akan digunakan adalah penelitian deskriptif komparatif. Menurut Subana (2001:89) menemukakan bahwa penelitian dengan format deskriptif adalah penelitian yang bertujuan untuk menjelaskan, meringkaskan kondisi dengan berbagai situasi, atau berbagai variabel yang timbul dimasyarakat berdasarkan apa adanya sesuai dengan kenyataan. 
Selanjutnya, Yusuf (2005:82) penelitian deskriptif adalah salah satu jenis penelitian yang bertujuan untuk mendeskripsikan secara sistematis, faktual dan akurat mengenai fakta-fakta dan sifat populasi tertentu dan mencoba menggabarkan fenomena secara mendetail apa adanya, yang artinya penelitian deskriptif adalah penelitian yang menggambarkan sesuatu yang sedang terjadi apa adanya.

\section{HASIL PENELITIAN DAN PEMBAHASAN}

Selanjutnya diperoleh kategorisasi Prokrastinasi Akademik Siswa di Sekolah dapat dijelaskan dalam tabel berikut:

Tabel 1. Kategorisasi Penskoran

\begin{tabular}{|c|c|c|c|}
\hline NO & Skor & $\mathbf{\%}$ & Kategori \\
\hline 1 & $\geq 105$ & $\geq 84$ & Sangat Tinggi \\
\hline 2 & $84-104$ & $67-83$ & Tinggi \\
\hline 3 & $63-83$ & $50-66$ & Sedang \\
\hline 4 & $42-62$ & $34-49$ & Rendah \\
\hline 5 & $\leq 41$ & $\leq 33$ & Sangat Rendah \\
\hline
\end{tabular}

Berdasarkan penyebaran instrumen prokrastinasi akademik siswa kepada 87 responden yang terdiri dari tiga kelas maka dapat diperoleh data sebagai berikut

Tabel 2. Data Tingkat Prokrastinasi Akademik Siswa

\begin{tabular}{|c|c|c|c|c|c|}
\hline No & Skor & Kriteria & $\begin{array}{l}\text { XII IPA } 1 \\
\text { (F) }\end{array}$ & $\begin{array}{c}\text { XII IPA } 2 \\
\text { (F) }\end{array}$ & $\begin{array}{c}\text { XII IPA } 3 \\
\text { (F) }\end{array}$ \\
\hline 1 & $\geq 105$ & Sangat Tinggi & 1 & 1 & 1 \\
\hline 2 & 84-104 & Tinggi & 21 & 15 & 1 \\
\hline 3 & $63-83$ & Sedang & 8 & 11 & 13 \\
\hline 4 & $42-62$ & Rendah & 1 & 0 & 5 \\
\hline 5 & $\leq 41$ & Sangat Rendah & 0 & 0 & 9 \\
\hline \multicolumn{3}{|c|}{ Jumlah Siswa } & 31 & 27 & 29 \\
\hline \multicolumn{3}{|c|}{ Jumlah Skor } & 2982 & 2531 & 2403 \\
\hline \multicolumn{3}{|c|}{ Rata-rata } & $\begin{array}{c}96,18 \\
\text { (Tinggi) }\end{array}$ & $\begin{array}{c}93,74 \\
\text { (Tinggi) }\end{array}$ & $\begin{array}{c}\mathbf{8 2 , 8 6} \\
\text { (Sedang) }\end{array}$ \\
\hline
\end{tabular}

Berdasarkan hasil data dari kelas XII IPA1 dengan jumlah 31 orang, prokrastinasi akademik siswa dengan rata-rata skor rata-rata 96,18 kategori “Tinggi”. 1 orang pada kategori "Sangat Tinggi”, 21 orang dengan kategori “Tinggi”, 8 orang pada kategori "Sedang”, dan 1 orang pada kategori "Rendah". Kelas XII IPA 2 dengan jumlah 27 orang dengan rata-rata skor 93,74 dengan kategori “Tinggi”. 1 orang pada kategori "Sangat Tinggi”, 15 orang pada kategori “Tinggi”, dan 11 orang pada kategori "Sedang”, selanjutnya hasil data dari kelas XII IPA 3 dengan jumlah 
29 orang siswa dengan rata-rata skor 82,86 dengan kategori "Sedang”. 1 orang pada kategori "Sangat Tinggi”, 1 orang pada kategori "Tinggi”, 13 orang pada kategori "Sedang", 5 orang pada kategori "Rendah", dan 9 orang pada kategori "Sangat Rendah". Jadi, berdasarkan hasil data di atas dapat disimpulkan bahwa XII IPA 1 yang paling "Tinggi” tingkat prokrastinasi akademiknya.

Dari hasil penelitian yang telah di lakukan maka data dari 87 siswa tersebut prokrastinasi akademik siswa pada kategori tinggi diperoleh rata-rata skor 90,92 sehingga hal ini mengarah pada negatif. Siswa di sekolah ini mengalami prokrastinasi akademik, yang di maksud dengan prokrastinasi akademik menurut Puswanti (2014:14) adalah kebiasaan untuk menunda-nunda pekerjaan yang merupakan suatu perilaku yang tidak efektif dalam penggunaan waktu. Menundanunda pekerjaan dapat dilakukan dalam berbagai kegiatan seperti menunda-nunda dalam mengerjakan ataupun menyelesaikan tugas-tugas akademik. Menurut Ramadhani (2018:377) prokrastinasi akademik merupakan perilaku yang tidak efektif dan efisien dalam memanfaatkan waktu dan adanya kecenderungan untuk tidak segera memulai suatu tindakan atau menunda tugas yang ingin dikerjakan sampai waktu berikutnya, sehingga perilaku tersebut dapat menghambat kesuksesan akademik individu itu sendiri.

Berdasarkan teori di atas bahwa prokrastinasi akademik adalah hal yang negatif, apabila hal ini dibiarkan maka tidak baik bagi siswa. Selanjutnya berdasarkan hasil penelitian (Abdullah, Thalib 2016) bahwa di sekolah SMA Negeri 2 Palu ini terdapat juga prokrastinasi akademik di sekolah, sejalan dengan itu maka diperlukannya penurunan atau pelayanan untuk mengatasi masalah tersebut.

Berdasarkan penelitian Ramadhani (2019:19) kepada mahasiswa prodi bimbingan dan konseling di Universitas PGRI Palembang bahwa mengungkapkan prokrastinasi akademik merupakan suatu tindakan menunda-nunda dalam mengerjakan sesuatu tugas, baik tugas perkuliahan ataupun tugas mengerjakan skripsi. Prokrastinasi juga merupakan perilaku yang negatif adapun beberapa komponen diantaranya; perilaku lalai, keragu-raguan, kurangnya ketepatan waktu, serta kurangnya perencanaan dalam melakukan sesuatu. Selanjutnya berdasarkan penelitian Ramadhani, dkk (2018:377) terdapat 24 mahasiswa terindikasi mengalami keterlambatan dalam menyelesaikan studi. Keterlambatan mahasiswa 
dalam menyelesaikan studi menggambarkan bahwa mahasiswa melakukan penundaan dalam melaksanakan tugas terutama dalam mengerjakan skripsi. Penundaan tersebut merupakan salah satu gejala dari prokrastinasi akademik mahasiswa dalam penyelesaian studi. Gambaran prokrastinasi akademik mahasiswa dalam mengerjakan skripsi dapat dilihat dari masih ditemukannya mahasiswa yang mengulang mata kuliah ataupun baru mengambil mata kuliah. Jadi berdasarkan hal tersebut dapat dikatakan bahwa mahasiswa melakukan prokrastinasi akademik bukan hanya pada penyelesaian skripsi, tetapi melakukan penundaan dalam melaksanakan tugas perkuliahan yang dijalaninya.

Berdasarkan penelitian saya yang dapat dikaitkan dengan penelitian Ramadhani, dkk terungkap bahwa prokrastinasi akademik tidak terjadi pada siswa saja akan tetapi prokrastinasi akademik juga terjadi kepada mahasiswa, sehingga dalam dunia pendidikan prokrastinasi akademik merupakan hal yang wajar akan tetapi dengan kewajaran tersebut perlunya mengatasi masalah tersebut

\section{KESIMPULAN}

Berdasarkan hasil penelitian yang diperoleh, maka dapat disimpulkan bahwa prokrastinasi akademik siswa SMA Negeri 1 Muara Sugihan kelas XII IPA 1 dengan rata-rata 96,18 pada kategori (Tinggi), kelas XII IPA 2 dengan ratarata 93,74 pada kategori (Tinggi), kelas XII IPA 3 dengan rata-rata 82,86 pada kategori (Sedang). Sehingga dari ketiga kelas yang telah diberikan instrumen prokrastinasi akademik berada pada kategoti (Tinggi) dengan rata-rata 90,92.

Dari hasil penelitian ini dapat disimpulkan rata-rata skor 90,92 dengan kategori tinggi. Berdasarkan hal tersebut maka perlunya adanya peninjauan dan pemberian layanan atau cara mengatasi masalah ini sehingga prokrastinasi akademik tidak berdampak tinggi yang dapat berdampak negatif pada siswa tersebut, untuk itu perlunya guru bimbingan dan konseling, kepala sekolah, dan konselor untuk bekerjasama dalam mengatasi masalah tersebut.

Berdasarkan data tersebut maka perlunya di atasi masalah ini sehingga kita dapat membantu kesuksesan siswa, salah satu cara yang mengatasi adalah memberikan layanan informasi, layanan bimbingan kelompok, dan layananlayanan lainya yang berkaitan dengan bimbingan dan konseling.

\section{DAFTAR PUSTAKA}

Abdullaah, T., Mansyur, Munifah. 2016. Upaya mereduksi perilaku prokrastinasi akademik melalui konseling kelompok dengan teknik self 
management (Studi kasus di kelas XI SMA negeri 2 Palu). Jurnal Konseling dan Psikoedukasi. 1(2). (1-14).

Irawan, P. 1996. Logika dan prosedur penelitian. Jakarta: STIA-LAN Press.

Puswanti. 2014. Upaya mereduksi prokrastinasi akademik melalui konseling kelompok melalui pendekatan behavioristik pada siswa SMK. Jurnal Psikopedagogia, 3(1).

Ramadhani, E, Putri, R. D, \& Istiqomah, V.A. 2018. Efektiveness of information services to reduce student academik procrastination in working thesis (experiment study on student of guidance and counseling Universitas PGRI Palembang). Prosiding Seminar Nasional ABKIN. Pekanbaru.

Ramadhani, E. 2019. Prokrastinasi akademik mahasiswa bimbingan dan konseling universitas pgri palembang dalam mengerjakan skripsi. Jurnal Wahana Konseling. 2(1).

Subana, M. 2001. Dasar-dasar penelitian ilmiah. Bandung: Pustaka Setia.

Yusuf, A.M. 2005. Metodologi penelitian. Padang:Unp Press. 